\title{
CULTURAL SELF-DETERMINATION OF A PERSONALITY IN POLYLINGUAL EDUCATIONAL ENVIRONMENT: METHODOLOGY, THEORY, PRACTICAL USAGE
}

\author{
Nadezhda E. Bulankina', Shtefani Peter ${ }^{2}$ \\ ${ }^{1}$ Novosibirsk Institute of Professional Skills Improvement \\ \& Vocational Retraining of Education Workers \\ 2, Krasny Prospekt, Novosibirsk, Russia, 630007 \\ ${ }^{2}$ Novosibirsk Branch of Cultural Center of GETE Institute (Germany) \\ 42, Maksima Gorkogo str., Novosibirsk, Russia, 630099
}

\begin{abstract}
This paper provides the view-point on cultural self-determination of a personality (CSD) in light of humanistic philosophy, the basics of which have been under the authors' investigation since the 90s until now. One of the most significant points of the authors' present-day research is to show the possibilities and perspectives of CSD for adaptation of the humanitarian approach towards 'education through life' for students; the latter is of paramount importance for the new generation, for our compatriots, and for our country, because along with this idea, the research under discussion paved the way for thoughts of making the most of the dual-purpose thinking of a personality in the educational process as a whole. The authors of the article consider the idea that the problem lies in the fact that Chaos is the foundation of the Universum, time and matter (objects) are not permanent constants, and Chaos is always a great variety. Reaching a sort of stability, Man finds himself in the situation of diversity. Then, there comes an existential crisis, which resolves in dualistic thinking. Thus, the authors of the article see in CSD one of the most significant mechanisms and ways out of the existential crisis, in which we, the people of the global communication-information civilization, have to live and work, to study new realia of the world and teach the new generation how to be adaptable and creative in the society of instability. From the view-point of the authors' pedagogical theory of CSD (2003), the paper also covers the technological aspects of providing the conditions for positive student motivation in the academic process, the basics of which depend on the intellectual component of a personality. The latter is based on the ability of both students and teachers to make most of the languages of the educational environment for fruitful communication in the light of the philosophy of Dialogism (M.M. Bachtin, V.S.Bibler, M.Buber, Yu. M.Lotman, M.S. Kagan, etc.).
\end{abstract}

Key words: cultural self-determination of a personality (CSD), languages, verbal and non-verbal communication in educational space, the Universum, conditions for positive motivation, dualistic thinking (DT), communicative competence, integrative processes (IP)

\section{Cultural Self-Determination of a Personality Mission}

In the framework of new conditions of educational activities at the beginning of the XXI century, CSD of a personality is characterized by the considerable complexity of social life because of the instability of human existence, in particular, the deterioration of public consciousness of traditional values, ideals, social relations, forms of real 
communication, and the means of saving life on the Earth (Filonov, 2013). This phenomenon concerns each person who understands and adequately interprets the situation of what is happening at the moment. By means of cultural devices of expression, one should formulate his attitude to it, and also find his way, place and 'voice' according to the surrounding changes (i.e. to choose the place to live and work, choose the profile/ the language of the profession, etc.). One cannot deny the concept that languages, both native and international, the linguistic culture of a personality, and the language components of the space around people, can help in fulfilling the above mentioned tasks, because they may be used for positive communication of mutual understanding, for harmony of communication and interaction aimed at educating Russian citizens (Sinenko et al., 2016) and developing their moral values (Sinenko, 2015, Power, 2004).

Nobody would deny this concept. As is the case, the question of today, is the following, 'Has the mission under discussion been fulfilled to the fullest, at our present day schools, both primary and secondary, universities and colleges, which are currently being modernized?' It is a pity, but our answer is "No". But what are we still doing? Until now, we have been discussing the problem in varied aspects, from different viewpoints, in a dualistic manner and style of conversation, and everywhere - in the classroom, on TV and on the Internet, in the Academy of Sciences, and among the general population. Theory and practice, and modern trends and technologies are the focus of the attention of educators and researchers at conferences and seminars. Yet we are still discussing how to improve our language culture, i.e. linguistic literacy of both the youngsters and our peers, and their communicative abilities for the sake of humanitarian self-organization (Bulankina, 2013).

Thus, we have to admit the fact that CSD as the language realization of a personality, in its broad sense (Vygotsky, 1991), is one of the most crucial locuses of society, education, and a student's personality. Along with it, there comes the question of discovering the means of self-preservation and self-sufficiency, and of reconstructing his/her own value preferences and diverse social connections in both the basics of communication and integrative processes (IP).

\section{Methodology and Program Structure}

Making most of the philosophical concepts of Dialogism (M.M. Bachtin, V.S.Bibler, M.Buber, Yu. M.Lotman, M.S. Kagan, etc.) and the results of their investigation of the Natural Sciences (Bulankina, 2013; Sinenko, 2016), here, in the opus, the authors of the present research consider the idea according to which Chaos is the foundation of the Universum, and time and matter (objects) are not permanent constants. As is the case, Chaos is always of great variety, to be of paramount significance for the CSD of a personality. Reaching a sort of stability, one finds oneself in the position of diversity and instability. Then there comes an existential crisis, which resolves within dualistic thinking.

Languages in this matter may become the only instrument which is capable of sorting out our thoughts and ideas for the sake of some order, balance, and stability (Ter-Minasova, 2008). It is one of the basic functions of the language. An educated, well-read personality understands that personal responsibility (for words and for deeds/actions) is increasing, and changes daily, as does the social status and social responsibility of a person, because one needs to be in search of some other updated and constantly changing strategies and 
tactics for positive communication (based on different languages) via verbal/non-verbal, natural and artificial devices/languages, etc., which are constantly changing and being used in everyday life.

The efficient and positive communication is considered, in our research, as the cornerstone of CSD. In its turn, CSD is sure to become the goal, process, result, and technological instrument for the realization of the humanistic approach towards renovation of the educational environment as a whole. At the moment we need cultural communication of different quality, because today's communication has no bounds and needs new devices which are created for the sake of productive interaction, thanks to some integrative processes (IP) of paramount importance in the Universum without bounds.

In the background of global changes in the sphere of Education (in its broad essence), professionalism, skill and innovation, methodological and theoretical competence of a pedagogue, teacher, trainer, tutor, or professor remain essential and important factors in the successful formation of a holistic, balanced, and stable educational space in light of the solution of humanitarian self-organization of a personality. Thus, the revision of the relationship of the characteristics of a productive educational process can contribute to the understanding of modern teachers' projects which concern the interpretation of the results of the formation of a personality, the essence of which is CSD (cultural self-identity/ self-determination) as the manifestation of language consciousness and national identity, as well as the informed professional choice (Curtis, 2016, Baiborodov, 2016).

If a sufficiently advanced pedagogue (as a researcher and investigator) understands in which world Man lives/exists, he starts to realize the instability of the Universe, and to live and teach students according to the principles of dualistic thinking, which should be based on the principle of conceptual interaction of the Humanities and Natural Sciences. According to the authors' concept, philosophical and methodological readiness for innovative knowledge in the sphere of modern science and humanistic realia is of great importance for any teacher of any discipline in the Curriculum (Sinenko, \& Bulankina, 2016).

That is why the aim of the present research, first and foremost, is to focus the teacher's or investigator's attention on humanitarian problems via integrative processes (IP) in education for changing the choice of the program structure at a particular school (lyceum, gymnasium, high and secondary school, etc.). The authors stick to this very concept. Systematic philosophical, theoretical, and methodological research of the causes for the deficit of culture-oriented social activities could be of help for our communities of teachers in solving most of the humanitarian problems via integrative processes in education, based on dualistic thinking (DT). First and foremost, it concerns the problem of the CSD of students, who are language personalities with their own voices (individual languages) and communicative competence. The efficacy depends (according to our research) on the development situations and development tasks for students, and their choice of intellectual and emotional/motivational instruments/devices (Bulankina, 2017).

\section{Innovative Perspectives of the Theoretical and Technological Research}

The results of our investigation are based on the innovative efforts of those teachers (both in the Humanities and Natural Sciences), who are encouraged by further innovative studies about the new knowledge and humanistic realia of the modern age from the view- 
point of humanistic philosophy. The likely pedagogues, along with their innovative community, consider the humanitarian approach to be the basis for culture-oriented educational activities, particularly when preference is given to personality's knowledge of students, to integrity of languages of poly-lingual education for the sake of both effective communication and interaction in the community of both teachers and students. One can witness the results of the cultural self-determination of their students/schoolchildren at so-called TALENT SHOWS in the last two decades in our West Siberian Region (Bulankina, 2013, 2017).

The pedagogues stick to the point that any academic discipline of Science and Liberal Education (chemistry, physics, and mathematics, and, of course, humanitarian subjects) has the humanitarian component, i.e. linguistic literacy and communicative competence, because it is not only a mandatory element of the educational process, but also an integral part of general culture of the participants of productive communication at the modern School. Although, they are in the know of the above-mentioned fact, at the same time they can hardly respond to the question positively that the language component of education as a reality is working to the fullest.

Thus, it does mean that for the School it is a must to continue research in this particular direction, maintaining the educational status of the institution, not only formally using the language (in all its forms) but also as a tool of expressive communication (the formulation of tasks, the presentation of information, programs, plans, staging occupations of different types, etc.). Varied Languages of Education (a word, gesture, facial expressions, the language of different disciplines/subjects, visual language information, the language of the author of the text in the textbook, the language of the participants of the educational process, the language of dance and singing, etc.) should be of use as important tools for a) self-knowledge, b) self-improvement, c) self-development, d) self-education, and e) self-education through life, i.e. for Cultural Self-Determination of a personality without bounds (Baiborodov, 2016, Bulankina, 2013, 2017).

At the same time, the authors of the article can, with confidence, point out that the above presented technological concept opens up significant opportunities to consider new realia of educational process from different points of view, allowing us to increase the use of cultural means of educational activities/practices for humanistic solution of the tasks set on the State level (State documents, Law of Education, the Concept of spirituallymoral education, federal state educational standards (FGOS), and other legal documents).

We come to the conclusion that poly-lingual culture as an important factor for the growth of a person's individual freedom plays the role of neutralization of the conflict of values (Blasi, 1993, Bondarevskaya, 2010, Nucci, 2004, 2008). Thanks to this neutralization, one can spot the growth of dualistic thinking/outlook of a person and the development of his vitality, i.e. CSD, which stimulates national identity, social identity, and professional choices of a personality (Bulankina, 2017). According to this strategy, the problem of professional-communicative discourse is considered to be the cornerstone of comprehension of the Humanities, which takes place in the process of a dialogue which lies in the basis of the communicative approach to Education. One can witness the perspectives or some of the findings in the long run. It concerns, first and foremost, the methodological and technological function of communicative paradigm $(\mathbf{C P})$ as a way of upward professional mobility and the professional development of educators, teachers and professors. $\mathbf{C P}$ is 
of paramount importance for both developing communicative competence and teaching creativity via creative humanitarian approach to education, i.e. CSD of a personality.

\section{Practical CSD Usage}

The research results show that the technological aspects of the communicative paradigm (CP) in Education based on the philosophy of dialogism should be of paramount importance. In our view, the solution to the above-mentioned technological problems likely lies in the statement according to which Dialogue is not just a form of interaction. It forms the basics for the subjects' content structured on integration (IP) which is dialogical in its essence where Dialogue is introduced via varied aspects of learning and teaching situations, both semantic and role-playing. Thanks to contrasting semantic positions there occurs a "split" of a frozen stock of knowledge, i.e. both scientific and educational knowledge go along with each other and make up the basics for the formation of functional literacy. The questions related to the formation of both language and communicative personality, and dominant convergent thinking are connected with the methodological readiness of any teacher to see the problems in the content of the subject, to discuss them together with the student, and to see the value of the student's ideas for instructional enhancements in the traditional classroom. In short, the corpus of the problems which are under discussion in the pedagogical community should cover the following significant questions Which content and methods of teaching should be used at the moment and in the future? Which is the most efficient methodology for developing modern teachers from the point of view of humanistic philosophy of education? and some other questions.

\section{Conclusion}

To sum up, our longitudinal investigation of numerous and varied innovations in modern Russian education over the last twenty-five years (Kuznetsova, 2012, Krylova, 2010, Bondarevskaya, 2010) allows us to highlight the macro-level context in which these changes occurred and continue to take place. In particular, it is far from being efficient in terms of the structures of economic, social, political and cultural control, as evidenced according to the results of numerous fundamental socio-philosophical, sociological and psycho-pedagogical research programs and projects. First and foremost, one can see no evidence of stability of varied contradictory requirements on the State level, and psychological balance and mobility of each of the participants of the educational process.

By the same token, the problematic locus of our education concerns the distrust of the student's opinion and the hierarchy of consciousness in the realia of our school. Although much has been done for supporting the creative professional discourse of a teacher, it is still important to continue to do research in this direction via educational development activities for the creative efforts of both investigators and pedagogues.

The sphere of communicative competence of the participants of the educational process, which is the foundation for creative speech and creative professional discourse of a teacher, deserves further scientific observation and investigation because the discourse is associated with the attempt to meet varied challenges of the multidimensional, ever-changing world, including linguistic and educational space, and revealing a holistic approach to varied problems in teaching both the Humanities and Natural Sciences. 
However, despite the crisis in some areas of society, including Russian education, it is important to underline the Russian Education preoccupation with renovations - it also brings to light a rather more amiable quality: a distinctive Russian capacity for being tolerant and remaining optimistic and persistent in achieving positive results in educational practice, and for choosing the path of positive changes.

\section{REFERENCES}

Baiborodov, A.Yu. (2016). Intercourse as the universal mode of being. Context and Reflection: Philosophy of the World and Human Being, (1), 74-87. (In Russ.).

Blasi, A. (1993). The development of identity: Some implications for moral functioning. In G.G. Noam \& T.E. Wren (Eds.). The moral self (pp. 99-122). Cambridge, MA: MIT Press.

Bondarevskaya, E.V., (2010). Dukhovno-nravstvennoe vospitanie uchashchikhsya v svete osobennostei sovremennoi sotsial'no-pedagogicheskoi situatsii i proekta novykh obrazovatel'nykh standartov. Izvestiya kafedry pedagogiki, (2), 3-11. (In Russ.).

Bulankina, N.Y. (2013). Gumanitarnaya samoorganizatsiya lichnosti. Filosofskie razmyshleniya. Novosibirsk: NGTU Publ. (In Russ.).

Bulankina, N.E. (2017a). Ot teorii k praktike. Razvivayushchee obuchenie! Kakoe ono! Prosveshchenie. Inostrannye yazyki. Retrieved from: http://iyazyki.prosv.ru/2017/06/developing-training/ (accessed 7.06.2017). (In Russ.).

Bulankina, N.Y. (2017b). Kul'turnoe samoopredelenie pedagoga: motivatsionnaya gotovnost' uchitelya $\mathrm{k}$ resheniyu zadach razvivayushchego obucheniya na urokakh inostrannogo yazyka. Prosveshchenie. Inostrannye yazyki. Retrieved from: http://iyazyki.prosv.ru/2017/06/cultural-self-determination/ (accessed 21.06.2017). (In Russ.).

Curtis, K. (2016). Multicultural Education-Learning English Through the NEI Method. Personality Formation, (3), 18-21.

Filonov, G.N. (2013). The reflexive potential of social transformations. Pedagoglka, (7), 43-50. (In Russ.).

Krylova O.N. (2010). Razvitie znanievoi traditsii v sovremennom soderzhanii otechestvennogo shkol'nogo obrazovaniya. St. Petersburg: LEMA Publ. (In Russ.).

Kuznetsova M.F. (2012). Philosophy of education reforms in the situation modern globalization. Bulletin of Krasnoyarsk State Pedagogical University, (4), 361-366. (In Russ.).

Nucci, L. (2004). Reflections on the moral self-construct. In D.K. Lapslay \& D. Narvaez (Eds.). Moral development, self and identity (pp. 111-132). Mahwah, New Jersey: Lawrence Erlbaum Associate.

Nucci, L., \& Powers, D.W. (2008). Social cognitive domain theory and moral education. In: L. Nucci, D. Narvaez \& T.Krettenauer (Eds.). Handbook of moral and character education (pp. 291-309). N.Y.: Routledge. doi: 10.4324/9780203114896.ch8

Sinenko, V.Ya., Kondratenko, A.P., \& Bulankina, N.E. (2016). Estestvennonauchnye znaniya v aspekte gumanitarnogo obrazovaniya. Novosibirsk: NIPKiPRO Publ. (In Russ.).

Sinenko, V.Ya. (2015). Formirovanie chelovecheskogo kapitala v sisteme obshchego obrazovaniya. Siberian Teacher, (4), 3. (In Russ.).

Ter-Minasova, S.G. (2008). Yazyk i mezhkul'turnaya kommunikatsiya. Moscow: SLOVO. (In Russ.).

Power, F.C. (2004). Moral self in community. In D.K. Lapslay \& D. Narvaez (Eds.). Moral development, self and identity (pp. 47-64). Mahwah, New Jersey: Lawrence Erlbaum Associates.

Vygotsky L.S. (1991). Problema kul'turnogo razvitiya rebenka (1928). Vestnik Moskovskogo universitetata. Seriya 14, (4), 5-18. (In Russ.). 
Article history:

Received 15 March 2017

Revised 22 June 2017

Accepted 30 June 2017

For citation:

Bulankina, N.E., Peter, S. (2017). Cultural Self-Determination of a Personality in Polylingual Educational Environment: Methodology, Theory, Practical usage. RUDN Journal of Psychology and Pedagogics, 14 (3), 282-289. DOI 10.22363/2313-1683-2017-14-3-282-289

\title{
Bio Note:
}

Nadezhda E. Bulankina - Doctor of Philosophy, Ph.D. in Pedagogics, Associate Professor, Head of the Department of Humanities Education, Novosibirsk Institute of Professional Skills Improvement \& Vocational Retraining of Education Workers (Russia). E-mail: NEBN@ yandex. $\mathrm{ru}$

Shtefani Peter - Ph.D. in Philosophy, director of Novosibirsk Branch of Cultural Center of GETE Institute (Germany). E-mail: info@nowosibirsk.goethe.org

\section{КУЛЬТУРНОЕ САМООПРЕДЕЛЕНИЕ ЛИЧНОСТИ В ПОЛИЯЗЫКОВОМ ОБРАЗОВАТЕЛЬНОМ ПРОСТРАНСТВЕ: МЕТОДОЛОГИЯ, ТЕОРИЯ, ПРАКТИКА}

\author{
Н.Е. Буланкина ${ }^{1}$, Ш. Петер ${ }^{2}$ \\ ${ }^{1}$ Новосибирский институт повышения квалификации и переподготовки работников \\ образования (НИПКиПРО) \\ Красный проспект, 2, Новосибирск, Россия, 630007 \\ ${ }^{2}$ Культурный центр Института Гете (Германия), филиал в г. Новосибирске \\ ул. Максима Горького, 42, Новосибирск, Россия, 630099
}

В статье предпринята попытка представить авторский концепт «культурное самоопределение личности» (КСЛ) с позиций гуманистической философии, основы которой стали предметом пролонгированного исследования еще в девяностые годы прошлого столетия, а его результаты - базой для продвижения некоторых актуальных на сегодня идей социально-философской концепции гуманизации образования в педагогическую практику культурно ориентированной направленности. По мнению авторов, для современного нестабильного социума, находящегося в условиях перманентного экзистенционального кризиса в мире, в экономике и человеческого «Я», становятся все более значимыми интеллектуальное начало и эмоциональное состояние субъекта при решении проблемы повышения мотивации к учению, к познанию и самопознанию с позиций гуманитарного подхода. Концепт о роли языковой составляющей в свете авторской теории культурного самоопределения личности в пространстве языков образования (естественные, искусственные, языки субъектных центров, профильные языки и др.) позиционируется в статье как важный фактор актуализации проблемы образования через всю жизнь в контексте философии диалогизма (М.М. Бахтин, М. Бубер, В.С. Библер, Ю.М. Лотман, М.С. Каган и др.). 
Ключевые слова: культурное самоопределение личности, языки, вербальная и невербальная коммуникация в образовании, коммуникативная компетенция, Универсум, условия повышения мотивации, дуалистическое мышление, коммуникативная компетенция, интегративные процессы

\section{История статьи:}

(C) Буланкина Н.Е., Петер Ш.., 2017

Поступила в редакцию: 15 марта 2017

Принята к печати: 30 июня 2017

\section{Для цитирования:}

Буланкина Н.Е., Петер Ш. Культурное самоопределение личности в полиязыковом образовательном пространстве: методология, теория, практика // Вестник Российского университета дружбы народов. Серия: Психология и педагогика. 2017. T. 14. № 3. С. 282-289. DOI 10.22363/2313-1683-2017-14-3-282-289

\section{Сведения об авторах:}

Буланкина Надежда Ефимовна - доктор философских наук, кандидат педагогических наук, доцент, заведующая кафедрой гуманитарного образования, профессор НИПКиПРО (Новосибирск, Россия). E-mail: NEBN@ yandex.ru

Петер Штефани - Ph.D., директор Культурного центра Института Гете (Германия), филиал в г. Новосибирске. E-mail: info@nowosibirsk.goethe.org 